\title{
Reference Values for Respiratory Muscle Strength in Children and Adolescents
}

\author{
Erik Hulzebos $^{\mathrm{a}}$ Tim Takken $^{\mathrm{a}}$ Elja A. Reijneveld ${ }^{\mathrm{b}}$ Mark M.G. Mulder ${ }^{\mathrm{a}}$ \\ Bart C. Bongers ${ }^{c, d}$
}

${ }^{a}$ Child Development \& Exercise Center, Wilhelmina Children's Hospital, University Medical Center Utrecht, Utrecht, The Netherlands; b Physical Therapy Science, Program in Clinical Health Sciences, University Medical Center Utrecht, Utrecht University, Utrecht, The Netherlands; ' Department of Epidemiology, Care and Public Health Research Institute (CAPHRI), Maastricht University, Maastricht, The Netherlands; ${ }^{\mathrm{d}}$ SOMT University of Physiotherapy, Amersfoort, The Netherlands

\section{Keywords}

Respiratory muscle strength · Tension time index · Children · Adolescents $\cdot$ Reference values

\begin{abstract}
Background: Measurement of respiratory muscle function is important in the diagnosis of respiratory muscle disease, respiratory failure, to assess the impact of chronic diseases, and/or to evaluate respiratory muscle function after treatment. Objectives: To establish reference values for maximal inspiratory and expiratory pressure, and the tension-time index at rest in healthy children and adolescents aged 8-19 years, as well as to present sex- and age-related reference centiles normalized for demographic and anthropometric determinants. Methods: In this cross-sectional observational study, demographic, anthropometric, and spirometric data were assessed, as well as data on respiratory muscle strength $\left(\mathrm{P}_{\text {Imax }}\right.$ and $\left.\mathrm{P}_{\text {Emax }}\right)$ and work of breathing at rest $\left(\mathrm{T}_{\mathrm{T} 0.1}\right)$, in a total of 251 children (117 boys and 134 girls; mean age $13.4 \pm$ 2.9 years). Reference values are presented as reference centiles developed by use of the lambda, mu, sigma method. Results: Boys had significantly higher $\mathrm{P}_{\operatorname{Imax}}$ and $\mathrm{P}_{\text {Emax }}$ values. Next to sex and age, fat-free mass appeared to be an impor-
\end{abstract}

\begin{tabular}{ll}
\hline KARGER & $\begin{array}{l}\text { (c) } 2018 \text { The Author(s) } \\
\text { Published by S. Karger AG, Basel }\end{array}$ \\
E-Mail karger@karger.com & This article is licensed under the Creative Commons Attribution- \\
www.karger.com/res & $\begin{array}{l}\text { NonCommercial-NoDerivatives 4.0 International License (CC BY- } \\
\text { NC-ND) (http://www.karger.com/Services/OpenAccessLicense). } \\
\text { Usage and distribution for commercial purposes as well as any dis- } \\
\text { tribution of modified material requires written permission. }\end{array}$
\end{tabular}

tant predictor of respiratory muscle strength. Reference centiles demonstrated a slight, almost linear increase in $\mathrm{P}_{\text {Imax }}$ with age in boys, and a less steep increase with age in girls. $\mathrm{T}_{\mathrm{T} 0.1}$ values did not differ between boys and girls and decreased linearly with age. Conclusion: This study provides reference values for respiratory muscle strength and work of breathing at rest. In addition to sex and age, fat-free mass was found to be an important predictor of respiratory muscle strength in boys and girls.

(C) 2018 The Author(s) Published by S. Karger AG, Basel

\section{Introduction}

Measurement of respiratory muscle function is important in the diagnosis of respiratory muscle disease and respiratory failure [1]. It is also an important tool to assess the impact of chronic diseases or to evaluate respiratory muscle function after treatment [2]. A commonly used method to quantify respiratory muscle strength is the measurement of maximal inspiratory $\left(\mathrm{P}_{\text {Imax }}\right)$ and expiratory $\left(\mathrm{P}_{\mathrm{Emax}}\right)$ mouth pressures [1]. Measurements of $\mathrm{P}_{\mathrm{Imax}}$ and $\mathrm{P}_{\text {Emax }}$ are volitional and noninvasive tests, giving an estimation of the inspiratory and expiratory muscle

H.J. (Erik) Hulzebos, PT, PhD

Child Development and Exercise Center, University Medical Center Utrecht KB.02.056.0, PO Box 85090

NL-3508 AB Utrecht (The Netherlands)

E-Mail h.hulzebos@umcutrecht.nl 
strength. $\mathrm{P}_{\text {Imax }}$ and $\mathrm{P}_{\text {Emax }}$ measurements are the most widely accepted noninvasive methods used to assess respiratory muscle strength [1]. These tests are commonly used in children and/or adolescents with neuromuscular disorders [2] and cystic fibrosis [3, 4].

Another noninvasive method to assess respiratory muscle function in children is the tension-time index of the inspiratory muscles $\left(\mathrm{T}_{\mathrm{T} 0.1}\right): \mathrm{T}_{\mathrm{T} 0.1}=\left(\mathrm{P}_{0.1} / \mathrm{P}_{\text {Imax }}\right) \times\left(\mathrm{T}_{\mathrm{I}} /\right.$ $\mathrm{T}_{\text {TOT }}$ ), where $\mathrm{P}_{0.1}$ is the mean inspiratory pressure estimated from the measure of mouth occlusion pressure $\left(\mathrm{P}_{0.1}\right), \mathrm{P}_{\text {Imax }}$ is the maximal inspiratory pressure, and $\mathrm{T}_{\mathrm{I}} /$ $\mathrm{T}_{\text {TOT }}$ is the inspiratory time ratio $[5,6]$. It is a dimensionless index relating the force developed by the respiratory muscles to the time that they are being used [5]. The determination of work of breathing $\left(\mathrm{T}_{\mathrm{T} 0.1}\right)$ thus integrates all the components that may affect the respiratory muscles while breathing at rest, including timing of the breathing cycle, inspiratory demand at rest, and maximal inspiratory force reserve. $\mathrm{T}_{\mathrm{T} 0.1}$ is an index that allows a more complete analysis of inspiratory muscle performance in the clinical setting than the use of $\mathrm{P}_{\mathrm{Imax}}$ only [5]. $\mathrm{T}_{\mathrm{T} 0.1}$ is easily measured and can be clinically useful in assessing progressive respiratory muscle dysfunction in children with cystic fibrosis $[4,5,7]$ and in children with a neuromuscular disorder [8], and may provide accurate prediction of extubation outcome in mechanically ventilated children [9]. Hayot et al. [6] have found that the tensiontime index $\left(\mathrm{T}_{\mathrm{T} 0.1}\right)$, given by $\left(\mathrm{P}_{0.1} / \mathrm{P}_{\text {Imax }}\right) \times\left(\mathrm{T}_{\mathrm{I}} / \mathrm{T}_{\mathrm{TOT}}\right)$, would be more reliable to assess the overall inspiratory muscle activity.

For a correct interpretation of $\mathrm{P}_{\text {Imax }}, \mathrm{P}_{\mathrm{Emax}}$, and $\mathrm{T}_{\mathrm{T} 0.1}$ measurements in clinical practice, it is necessary to compare data from an individual child with those from healthy children. Values obtained from healthy children provide clinicians with information about normal respiratory muscle function and can be used as reference values to interpret individual test results. Several studies established reference values for $\mathrm{P}_{\text {Imax }}$ and $\mathrm{P}_{\mathrm{Emax}}$, and in some studies children and adolescents were included [10-17]. However, the considerable interindividual variability in $\mathrm{P}_{\text {Imax }}$ and $\mathrm{P}_{\mathrm{Emax}}$ values makes the interpretation of individual test results difficult. In addition, reference values for $\mathrm{T}_{\mathrm{T} 0.1}$ are lacking in these studies. Recently, Mellies et al. [18] investigated reference values for $\mathrm{P}_{\text {Imax }}$ and $\mathrm{T}_{\mathrm{T} 0.1}$ in children aged 6-16 years old, including percentile curves of $\mathrm{P}_{\text {Imax }}$ values to facilitate the interpretation of individual test results. However, reference values for $\mathrm{P}_{\mathrm{Emax}}$ and for adolescents from 17 to 19 years old are lacking in this study. Furthermore, in this study, determinants that affect the functions of the respiratory muscles in healthy children were not studied. $\mathrm{P}_{\operatorname{Imax}}$ and $\mathrm{P}_{\mathrm{Emax}}$ values seem to increase with age and seem to be higher in boys than in girls $[10,15]$. Additionally, it is known that in children with cystic fibrosis, muscle mass may be an important determinant of inspiratory muscle weakness $[4,5]$. Body mass, body mass index (BMI), and body height may be predictive for $\mathrm{P}_{\text {Imax }}$ and $\mathrm{P}_{\text {Emax }}$, however, the results of previous research are inconclusive $[13,15]$, and the predictive value of muscle mass (fat-free mass, FFM) in healthy children and adolescents has not been studied before. Therefore, the aim of the current study was to establish reference values for $\mathrm{P}_{\operatorname{Imax}}, \mathrm{P}_{\mathrm{Emax}}$, and $\mathrm{T}_{\mathrm{T} 0.1}$ at rest in healthy children and adolescents aged $8-19$ years old, as well as to represent reference values in centile curves corrected for anthropometric determinants.

\section{Material and Methods}

\section{Participants}

In this cross-sectional observational study, healthy nonathletic Dutch children and adolescents ranging in age from 8 to 19 years were recruited from primary and secondary schools that were randomly selected and asked to facilitate this study throughout the Netherlands. The research protocols were approved by the institutional review board of the University Medical Center Utrecht, and written informed consent was obtained from the parents or legal guardians and, if older than 12 years of age, from the children as well. All potential participants completed a modified Physical Activity Readiness Questionnaire (PAR-Q) prior to participation. Participants with cardiovascular, pulmonary, neurological, or musculoskeletal disease, or those answering yes to one or more questions of the modified PAR-Q were excluded. Children were tested in a quiet room at their own school or at the exercise laboratory of the hospital.

\section{Measurements}

Protocol

First, anthropometric measurements were performed, followed by spirometric measurements (forced expiratory volume in $1 \mathrm{~s}\left[\mathrm{FEV}_{1}\right]$ and forced vital capacity $\left.[\mathrm{FVC}]\right)$ and measurements of respiratory muscle function $\left(\mathrm{P}_{0.1}, \mathrm{P}_{\text {Imax }}\right.$, and $\left.\mathrm{P}_{\text {Emax }}\right)$. During the spirometric measurements and respiratory muscle function testing, participants were tested at rest in a sitting position while a nose clip was used. A period of $5 \mathrm{~min}$ of rest took place between different measurements.

\section{Anthropometry}

Each participant's body mass (determined to the nearest $0.1 \mathrm{~kg}$ ) and body height (determined to the nearest $0.5 \mathrm{~cm}$ ) were measured with an electronic scale (Seca 803, Seca, Hamburg, Germany) and a metric measuring tape with a wall stop (Seca 206, Seca), respectively. Sitting height was also measured and was used to predict age from peak height velocity (PHV) as a marker of biological maturity. BMI (in $\mathrm{kg} \bullet \mathrm{m}^{2}$ ) was calculated as the body mass divided by the body height squared. The equation of Haycock et al. [19] was used to estimate body surface area (BSA, in $\mathrm{m}^{2}$ ). Subcutaneous fat 
Table 1. Participants' characteristics

\begin{tabular}{|c|c|c|c|c|c|c|}
\hline \multirow[b]{2}{*}{ Age, years } & \multicolumn{2}{|c|}{ Boys $(n=117)$} & \multicolumn{2}{|c|}{ Girls $(n=134)$} & \multirow{2}{*}{$\frac{p \text { value }}{0.885}$} & \multirow{2}{*}{$\begin{array}{l}95 \% \mathrm{CI} \\
-0.7 \text { to } 0.8\end{array}$} \\
\hline & $13.4 \pm 3.0$ & 8.1 to 19.0 & $13.4 \pm 2.9$ & 8.2 to 19.0 & & \\
\hline Body mass, $\mathrm{kg}$ & $51.6 \pm 15.7$ & 23.6 to 104.2 & $50.6 \pm 13.8$ & 21.5 to 97.8 & 0.585 & -2.6 to 4.7 \\
\hline Body height, $\mathrm{cm}$ & $161 \pm 15$ & 126 to 191 & $158 \pm 12$ & 123 to 187 & 0.107 & -0.6 to 6.4 \\
\hline Age from PHV, years & $-0.4 \pm 2.4$ & -4.0 to 4.0 & $1.1 \pm 2.1$ & -3.4 to 4.0 & $<0.001^{* * *}$ & -2.1 to -0.9 \\
\hline BMI & $19.3 \pm 3.1$ & 13.4 to 31.5 & $19.8 \pm 3.3$ & 13.2 to 29.4 & 0.305 & -1.2 to 0.4 \\
\hline $\mathrm{BSA}, \mathrm{m}^{2}$ & $1.51 \pm 0.30$ & 0.90 to 2.32 & $1.48 \pm 0.26$ & 0.85 to 2.27 & 0.458 & -0.04 to 0.09 \\
\hline Body fat, \% & $17.6 \pm 5.0$ & 9.9 to 30.7 & $22.8 \pm 4.8$ & 13.7 to 35.5 & $<0.001^{* * *}$ & -6.4 to -4.0 \\
\hline FFM, kg & $42.2 \pm 12.0$ & 21.2 to 74.0 & $38.7 \pm 9.3$ & 17.3 to 63.1 & $0.01^{*}$ & 0.8 to 6.2 \\
\hline $\mathrm{FEV}_{1}, \%$ of pred. $^{\mathrm{a}}$ & $98.2 \pm 12.2$ & 73.9 to 133.5 & $96.8 \pm 11.7$ & 64.2 to 127.1 & 0.367 & -1.7 to 4.7 \\
\hline FVC, $\%$ of pred. ${ }^{a}$ & $95.8 \pm 11.8$ & 73.6 to 133.9 & $93.3 \pm 11.3$ & 66.3 to 122.0 & 0.109 & -0.6 to 5.7 \\
\hline
\end{tabular}

Values are presented as mean \pm SD and range. BMI, body mass index; BSA, body surface area; CI, confidence interval; $\mathrm{FEV}_{1}$, forced expiratory volume in $1 \mathrm{~s} ; \mathrm{FFM}$, fat-free mass; FVC, forced vital capacity; PHV, peak height velocity. ${ }^{*} p<0.05{ }^{* * *} p<0.001{ }^{\text {a }}$ In this case, $n=103$ for boys and $n=109$ for girls.

distribution was measured with a Harpenden skinfold caliper (Baty International, West Sussex, UK) at triceps, biceps, subscapular, and suprailiac sites on the right side of the body [20]. The sum of the four skinfolds (in $\mathrm{mm}$ ) was used to estimate the body density with standard equations [20]. The percentage of body fat and the FFM (in $\mathrm{kg}$ ) were estimated with a modification of the Siri equation proposed by Weststrate and Deurenberg [21].

\section{Spirometry}

$\mathrm{FEV}_{1}$ and FVC were measured using the calibrated ZAN 300 $\mathrm{CO}$ diffusion (nSpire Health GmbH, Oberthulba, Germany), combined with ZAN-Tech software, according to ATS/ERS standards [22]. The results were compared with predicted values for healthy subjects matched for sex, age, and body height [23].

\section{Respiratory Muscle Function}

$\mathrm{P}_{\text {Imax }}$ and $\mathrm{P}_{\text {Emax }}$ were measured using a calibrated portable hand-held mouth pressure meter (Micro RPM, Micro Medical Ltd., Chatham, UK), and $\mathrm{P}_{0.1}$ and the inspiratory time ratio $\left(\mathrm{T}_{\mathrm{I}} /\right.$ $\mathrm{T}_{\text {TOT }}$ ) were measured using the ZAN $300 \mathrm{CO}$ diffusion (nSpire Health $\mathrm{GmbH}$ ) combined with ZAN-Tech software, all according to ATS/ERS standards [1]. $\mathrm{P}_{\text {Imax }}$ was measured from residual volume upon a maximal inspiratory effort against an occluded airway. $\mathrm{P}_{\text {Emax }}$ was measured from total lung capacity performing a maximal expiratory effort against an occluded airway. After a practice session, $\mathrm{P}_{\text {Imax }}$ and $\mathrm{P}_{\mathrm{Emax}}$ measurements were repeated three times, and the maximum value achieved was recorded. $\mathrm{P}_{0.1}$ was calculated as the airway pressure generated $100 \mathrm{~ms}$ after an occlusion while the participant was breathing quietly at rest. After a habituation session, at least three random airway occlusions were performed and the average $\mathrm{P}_{0.1}$ value at rest was calculated. Subsequently, $\mathrm{P}_{0.1} / \mathrm{P}_{\text {Imax }}$ ratio (\%) was calculated, representing inspiratory muscle load. Finally, $\mathrm{T}_{\mathrm{T} 0.1}$ was determined with the highest $\mathrm{P}_{\text {Imax }}$ and the average $\mathrm{P}_{0.1}$ value with its corresponding average inspiratory time of the respiratory cycle $\left(\mathrm{T}_{\mathrm{I}}\right)$ and the total duration of the respiratory cycle $\left(\mathrm{T}_{\mathrm{TOT}}\right)$ using the following equation: $\mathrm{T}_{\mathrm{T} 0.1}=\left(\mathrm{P}_{0.1} / \mathrm{P}_{\text {Imax }}\right) \times\left(\mathrm{T}_{\mathrm{I}} / \mathrm{T}_{\mathrm{TOT}}\right)[6]$.

Pediatric Norms for Respiratory Muscle Strength

\section{Statistical Analysis}

Statistical analyses were performed using Statistical Package for the Social Sciences for Windows (version 20.0; IBM, SPSS Inc., Chicago, IL, USA). Data are presented as mean, standard deviation $(\mathrm{SD})$, and range. Normality of respiratory muscle function data $\left(\mathrm{P}_{\text {Imax }}, \mathrm{P}_{\text {Emax }}\right.$, and $\left.\mathrm{T}_{\mathrm{T} 0.1}\right)$ was checked using histograms and $\mathrm{Q}-\mathrm{Q}$ plots. Comparisons of anthropometric, spirometric, and respiratory muscle function parameters between boys and girls were completed by independent samples $t$ tests.

Pearson correlation coefficients were performed to examine the relationships between anthropometric variables and respiratory muscle function data $\left(\mathrm{P}_{\mathrm{Imax}}, \mathrm{P}_{\mathrm{Emax}}\right.$, and $\left.\mathrm{T}_{\mathrm{T} 0.1}\right)$. Age- and sexrelated reference centiles for absolute $\mathrm{P}_{\text {Imax }}, \mathrm{P}_{\mathrm{Emax}}$, and $\mathrm{T}_{\mathrm{T} 0.1}$, were derived using the lambda, mu, sigma (LMS) method as introduced by Cole $[24,25]$, using LMS Chartmaker Pro version 2.5 (Medical Research Council, London, UK). A $p$ value $<0.05$ was considered statistically significant.

\section{Results}

Of the initial 266 children and adolescents who were willing to participate and gave written informed consent, 251 were included in the study ( 117 boys and 134 girls). Five participants $(1.9 \%)$ were excluded because of musculoskeletal disease, $2(0.8 \%)$ had neurological disease, 2 $(0.8 \%)$ had cardiovascular disease, $3(1.1 \%)$ felt pain in their chest when performing physical activity in the month before testing, and 3 (1.1\%) were not tested because of scheduling issues. Of these 251 children and adolescents (117 boys and 134 girls; mean age $13.4 \pm 2.9$ years, range 8-19 years), data on $\mathrm{FEV}_{1}, \mathrm{FVC}$, and $\mathrm{T}_{\mathrm{T} 0.1}$ were missing in 37 participants $(14.7 \%)$, data on $\mathrm{FEV}_{1}$ 
Table 2. Participants' characteristics per age group

\begin{tabular}{|c|c|c|c|c|c|}
\hline & \multicolumn{5}{|c|}{ Age category, years } \\
\hline & 8 and 9 & 10 and 11 & 12 and 13 & 14 and 15 & $16-18$ \\
\hline Boys & $n=19$ & $n=22$ & $n=27$ & $n=22$ & $n=27$ \\
\hline Age, years & $9.1 \pm 0.6$ & $11.0 \pm 0.6$ & $13.0 \pm 0.6$ & $15.1 \pm 0.5$ & $17.4 \pm 1.0$ \\
\hline Body mass, $\mathrm{kg}$ & $34.6 \pm 4.9$ & $41.2 \pm 7.4$ & $46.9 \pm 9.3$ & $65.6 \pm 14.3$ & $65.3 \pm 9.7$ \\
\hline Body height, $\mathrm{cm}$ & $140 \pm 7$ & $151 \pm 8$ & $158 \pm 8$ & $175 \pm 7$ & $177 \pm 6$ \\
\hline Age from PHV, years & $-3.6 \pm 0.4$ & $-2.3 \pm 0.6$ & $-1.0 \pm 0.7$ & $1.2 \pm 0.8$ & $2.8 \pm 0.8$ \\
\hline BMI & $17.7 \pm 2.4$ & $17.9 \pm 2.3$ & $18.6 \pm 2.4$ & $21.4 \pm 4.2$ & $20.8 \pm 2.3$ \\
\hline $\mathrm{BSA}, \mathrm{m}^{2}$ & $1.15 \pm 0.10$ & $1.31 \pm 0.15$ & $1.43 \pm 0.17$ & $1.78 \pm 0.22$ & $1.78 \pm 0.16$ \\
\hline Body fat, \% & $18.6 \pm 5.1$ & $18.4 \pm 4.8$ & $17.4 \pm 5.3$ & $17.8 \pm 6.0$ & $16.5 \pm 3.7$ \\
\hline FFM, kg & $28.0 \pm 3.0$ & $33.4 \pm 4.8$ & $38.4 \pm 5.8$ & $53.2 \pm 8.2$ & $54.3 \pm 6.7$ \\
\hline $\mathrm{FEV}_{1}, \%$ of pred. & $93.8 \pm 8.2$ & $92.5 \pm 7.2$ & $94.9 \pm 9.8^{\mathrm{a}}$ & $98.6 \pm 10.9^{\mathrm{b}}$ & $110.3 \pm 13.9^{c}$ \\
\hline FVC, $\%$ of pred. & $90.2 \pm 7.2$ & $88.7 \pm 6.7$ & $93.6 \pm 9.5^{\mathrm{a}}$ & $97.4 \pm 10.2^{\mathrm{b}}$ & $108.2 \pm 12.5^{c}$ \\
\hline Girls & $n=23$ & $n=21$ & $n=37$ & $n=24$ & $n=29$ \\
\hline Age, years & $9.1 \pm 0.6$ & $11.1 \pm 0.5$ & $13.0 \pm 0.6$ & $14.9 \pm 0.6$ & $17.5 \pm 1.0$ \\
\hline Body mass, $\mathrm{kg}$ & $32.7 \pm 6.4$ & $43.6 \pm 8.0$ & $50.3 \pm 9.6$ & $60.4 \pm 10.7$ & $61.9 \pm 9.8$ \\
\hline Body height, $\mathrm{cm}$ & $138 \pm 6$ & $153 \pm 6$ & $162 \pm 7$ & $169 \pm 6$ & $166 \pm 7$ \\
\hline Age from PHV, years & $-2.3 \pm 0.6$ & $-0.5 \pm 0.6$ & $1.1 \pm 0.7$ & $2.6 \pm 0.5$ & $3.7 \pm 0.4$ \\
\hline BMI & $17.0 \pm 2.7$ & $18.7 \pm 2.7$ & $19.2 \pm 3.1$ & $21.2 \pm 3.1$ & $22.3 \pm 2.3$ \\
\hline $\mathrm{BSA}, \mathrm{m}^{2}$ & $1.11 \pm 0.13$ & $1.35 \pm 0.15$ & $1.49 \pm 0.17$ & $1.68 \pm 0.17$ & $1.69 \pm 0.16$ \\
\hline Body fat, $\%$ & $21.9 \pm 5.5$ & $23.5 \pm 5.7$ & $21.7 \pm 4.7$ & $23.6 \pm 4.4$ & $23.8 \pm 3.8$ \\
\hline FFM, kg & $25.3 \pm 3.6$ & $33.0 \pm 4.2$ & $39.1 \pm 5.9$ & $45.8 \pm 6.2$ & $46.9 \pm 5.6$ \\
\hline $\mathrm{FEV}_{1}, \%$ of pred. & $92.2 \pm 7.0$ & $87.8 \pm 10.0$ & $95.1 \pm 8.7^{\mathrm{d}}$ & $101.7 \pm 11.4^{\mathrm{e}}$ & $108.0 \pm 10.1^{\mathrm{f}}$ \\
\hline FVC, \% of pred. & $89.0 \pm 7.0$ & $84.3 \pm 10.3$ & $90.2 \pm 8.9^{\mathrm{d}}$ & $100.5 \pm 9.8^{\mathrm{e}}$ & $103.9 \pm 8.0^{\mathrm{f}}$ \\
\hline
\end{tabular}

Values are presented as mean \pm SD. BMI, body mass index; BSA, body surface area; $\mathrm{FEV}_{1}$, forced expiratory volume in $1 \mathrm{~s}$; FFM, fat-free mass; FVC, forced vital capacity; PHV, peak height velocity. ${ }^{a}$ In this case, $n=22$. ${ }^{\mathrm{b}}$ In this case, $n=17 .{ }^{\mathrm{c}}$ In this case, $n=23 .{ }^{\mathrm{d}}$ In this case, $n=25 .{ }^{\mathrm{e}}$ In this case, $n=18 .{ }^{\mathrm{f}}$ In this case, $n=22$.

and FVC were missing in 2 participants $(0.8 \%)$, and data on $\mathrm{T}_{\mathrm{T} 0.1}$ were missing in 4 participants $(1.6 \%)$. Characteristics of the participants are shown in Table 1 and per age group in Table 2. All children and adolescents were within normal range for body mass and body height [26], no participant had begun smoking or had cardiorespiratory pathology, and all participants' lung volumes were comparable to those previously reported within this age range [23]. Boys had statistically significant less biological maturity, lower percentage of body fat, and higher FFM compared with girls.

Respiratory muscle function data were normally distributed and results are shown in Table 3 and per age group in Table 4. Mean \pm SD values for $\mathrm{P}_{\text {Imax }}$ and $\mathrm{P}_{\mathrm{Emax}}$ were $106 \pm 28 \mathrm{~cm} \mathrm{H}_{2} \mathrm{O}$ and $127 \pm 35 \mathrm{~cm} \mathrm{H}_{2} \mathrm{O}$, respectively, whereas the mean value for $\mathrm{T}_{\mathrm{T} 0.1}$ was $0.011 \pm$ 0.006 . Boys had statistically significant higher values for $\mathrm{P}_{\text {Imax }}$ and $\mathrm{P}_{\text {Emax }}$ compared with girls, whereas $\mathrm{T}_{\mathrm{T} 0.1}, \mathrm{P}_{0.1}$, and the inspiratory time ratio $\left(\mathrm{T}_{\mathrm{I}} / \mathrm{T}_{\mathrm{TOT}}\right)$ were not different between boys and girls. Correlation coefficients be- tween anthropometric measurements and $\mathrm{P}_{\text {Imax }}, \mathrm{P}_{\text {Emax }}$, and $\mathrm{T}_{\mathrm{T} 0.1}$ are shown in Table 5. Age, body mass, body height, age from PHV, BSA, and FFM were significantly positively correlated with $\mathrm{P}_{\text {Imax }}$ and $\mathrm{P}_{\text {Emax }}$ ( $r$ values ranging from 0.271 to 0.537 ) and negatively correlated with $\mathrm{T}_{\mathrm{T} 0.1}$ ( $r$ values ranging from -0.249 to -0.484 ). FFM had the highest correlation with $\mathrm{P}_{\mathrm{Imax}}$ and $\mathrm{P}_{\mathrm{Emax}}$ in both boys and girls. BMI was only significantly correlated with $\mathrm{P}_{\mathrm{I}-}$ $\max$ and $\mathrm{P}_{\mathrm{Emax}}$ in boys and girls, and the percentage of body fat was only significantly correlated with $\mathrm{T}_{\mathrm{T} 0.1}$ in boys.

Absolute $\mathrm{P}_{\text {Imax }}$ values showed a slight and almost linear increase with age in boys (Fig. 1a), and a less steep increase with age girls (Fig. 1b). Normalized for FFM, as best predictor, values for $\mathrm{P}_{\text {Imax }}$ decreased with age in both boys and girls (Fig. 1c, d). In boys, $\mathrm{P}_{\mathrm{Emax}}$ values slightly decreased from 8 to 10 years of age and then linearly increased with age (Fig. 2a), whereas $P_{\text {Emax }}$ values in girls slightly increased with age (Fig. 2b). Normalized for FFM, values for $\mathrm{P}_{\mathrm{Emax}}$ decreased with age in boys as well as in 
Table 3. Participants' respiratory muscle function

\begin{tabular}{lcccccc}
\hline Variable & Boys $(n=117)$ & & Girls $(n=134)$ & & $p$ value & 95\% CI \\
\hline $\mathrm{P}_{0.1}, \mathrm{~cm} \mathrm{H}_{2} \mathrm{O}^{\mathrm{a}}$ & $0.23 \pm 0.13$ & 0.06 to 0.89 & $0.23 \pm 0.11$ & 0.05 to 0.67 & 0.998 & -0.03 to 0.03 \\
$\mathrm{~T}_{\mathrm{I}} / \mathrm{T}_{\mathrm{TOT}}{ }^{\mathrm{a}}$ & $0.46 \pm 0.05$ & 0.28 to 0.56 & $0.46 \pm 0.05$ & 0.35 to 0.64 & 0.699 & -0.02 to 0.01 \\
$\mathrm{P}_{\mathrm{Imax}}, \mathrm{cm} \mathrm{H}_{2} \mathrm{O}$ & $113 \pm 27$ & 61 to 177 & $101 \pm 27$ & 53 to 171 & $0.001^{* *}$ & 5 to 19 \\
$\mathrm{P}_{\mathrm{Emax}}, \mathrm{cm} \mathrm{H}_{2} \mathrm{O}$ & $137 \pm 36$ & 73 to 263 & $118 \pm 30$ & 36 to 234 & $<0.001^{* * *}$ & 10 to 27 \\
$\mathrm{P}_{0.1} / \mathrm{P}_{\text {Imax }}, \%^{\mathrm{a}}$ & $0.22 \pm 0.13$ & 0.04 to 0.70 & $0.25 \pm 0.16$ & 0.04 to 1.12 & 0.074 & -0.074 to 0.003 \\
$\mathrm{~T}_{\mathrm{T} 0.1}$ a, b & $0.010 \pm 0.006$ & 0.002 to 0.030 & $0.011 \pm 0.006$ & 0.002 to 0.028 & 0.124 & -0.0030 to 0.0004 \\
\hline
\end{tabular}

Values are presented as mean $\pm \mathrm{SD}$ and range. $\mathrm{CI}$, confidence interval; $\mathrm{P}_{0.1}$, mouth occlusion pressure; $\mathrm{P}_{\text {Emax }}$, maximal expiratory pressure; $\mathrm{P}_{\text {Imax }}$, maximal inspiratory pressure; $\mathrm{T}_{\mathrm{I}} / \mathrm{T}_{\mathrm{TO}}$, inspiratory time ratio; $\mathrm{T}_{\mathrm{T} 0.1}$, tension time index. ${ }^{* *} p<0.01 ;{ }^{* * *} p<0.001 .{ }^{\mathrm{a}}$ In this case, $n=103$ for boys and $n=108$ for girls. ${ }^{\mathrm{b}}$ Calculated as: $\mathrm{T}_{\mathrm{T} 0.1}$, $\left(\mathrm{P}_{0.1} / \mathrm{P}_{\text {Imax }}\right) \times\left(\mathrm{T}_{\mathrm{I}} / \mathrm{T}_{\mathrm{TOT}}\right)$.

Table 4. Participants' respiratory muscle function per age group

\begin{tabular}{|c|c|c|c|c|c|}
\hline & \multicolumn{5}{|c|}{ Age category, years } \\
\hline & 8 and 9 & 10 and 11 & 12 and 13 & 14 and 15 & $16-18$ \\
\hline Boys & $n=19$ & $n=22$ & $n=27$ & $n=22$ & $n=27$ \\
\hline $\mathrm{P}_{0.1}, \mathrm{~cm} \mathrm{H}_{2} \mathrm{O}$ & $0.30 \pm 0.15^{\mathrm{b}}$ & $0.22 \pm 0.13$ & $0.22 \pm 0.08^{\mathrm{c}}$ & $0.28 \pm 0.19^{\mathrm{d}}$ & $0.16 \pm 0.06^{\mathrm{e}}$ \\
\hline $\mathrm{T}_{\mathrm{I}} / \mathrm{T}_{\mathrm{TOT}}$ & $0.46 \pm 0.04^{\mathrm{b}}$ & $0.47 \pm 0.05$ & $0.46 \pm 0.05^{\mathrm{c}}$ & $0.44 \pm 0.07^{\mathrm{d}}$ & $0.46 \pm 0.04^{\mathrm{e}}$ \\
\hline $\mathrm{P}_{\text {Imax }}, \mathrm{cm} \mathrm{H}_{2} \mathrm{O}$ & $89 \pm 13$ & $97 \pm 20$ & $118 \pm 27$ & $125 \pm 26$ & $126 \pm 24$ \\
\hline $\mathrm{P}_{\text {Emax }}, \mathrm{cm} \mathrm{H}_{2} \mathrm{O}$ & $117 \pm 25$ & $117 \pm 31$ & $132 \pm 26$ & $151 \pm 32$ & $161 \pm 43$ \\
\hline $\mathrm{P}_{0.1} / \mathrm{P}_{\text {Imax }}, \%$ & $0.32 \pm 0.16^{\mathrm{b}}$ & $0.24 \pm 0.12$ & $0.19 \pm 0.07^{c}$ & $0.22 \pm 0.14^{\mathrm{d}}$ & $0.13 \pm 0.05^{\mathrm{e}}$ \\
\hline $\mathrm{T}_{\mathrm{T} 0.1}^{\mathrm{a}}$ & $0.015 \pm 0.008^{b}$ & $0.012 \pm 0.007$ & $0.009 \pm 0.003^{c}$ & $0.010 \pm 0.006^{\mathrm{d}}$ & $0.006 \pm 0.002^{\mathrm{e}}$ \\
\hline Girls & $n=23$ & $n=21$ & $n=37$ & $n=24$ & $n=29$ \\
\hline $\mathrm{P}_{0.1}, \mathrm{~cm} \mathrm{H}_{2} \mathrm{O}$ & $0.28 \pm 0.10^{\mathrm{f}}$ & $0.23 \pm 0.10$ & $0.28 \pm 0.13^{\mathrm{g}}$ & $0.21 \pm 0.11^{\mathrm{i}}$ & $0.15 \pm 0.05^{j}$ \\
\hline $\mathrm{T}_{\mathrm{I}} / \mathrm{T}_{\mathrm{TOT}}$ & $0.46 \pm 0.05^{\mathrm{f}}$ & $0.45 \pm 0.05$ & $0.47 \pm 0.04^{\mathrm{g}}$ & $0.46 \pm 0.06^{\mathrm{i}}$ & $0.45 \pm 0.04^{j}$ \\
\hline $\mathrm{P}_{\text {Imax }}, \mathrm{cm} \mathrm{H}_{2} \mathrm{O}$ & $93 \pm 24$ & $91 \pm 22$ & $96 \pm 25$ & $112 \pm 23$ & $110 \pm 32$ \\
\hline $\mathrm{P}_{\text {Emax }}, \mathrm{cm} \mathrm{H}_{2} \mathrm{O}$ & $105 \pm 20$ & $106 \pm 26$ & $116 \pm 28$ & $134 \pm 33$ & $127 \pm 33$ \\
\hline $\mathrm{P}_{0.1} / \mathrm{P}_{\text {Imax }}, \%$ & $0.31 \pm 0.13^{\mathrm{f}}$ & $0.27 \pm 0.14$ & $0.31 \pm 0.21^{\mathrm{g}}$ & $0.20 \pm 0.14^{\mathrm{i}}$ & $0.15 \pm 0.06^{\mathrm{j}}$ \\
\hline $\mathrm{T}_{\mathrm{T} 0.1}^{\mathrm{a}}$ & $0.014 \pm 0.007^{\mathrm{f}}$ & $0.012 \pm 0.006$ & $0.013 \pm 0.006^{\mathrm{h}}$ & $0.010 \pm 0.007^{\mathrm{i}}$ & $0.007 \pm 0.003^{j}$ \\
\hline
\end{tabular}

Values are presented as mean $\pm \mathrm{SD} . \mathrm{P}_{0.1}$, mouth occlusion pressure; $\mathrm{P}_{\text {Emax }}$, maximal expiratory pressure; $\mathrm{P}_{\text {Imax }}$, maximal inspiratory pressure; $\mathrm{T}_{\mathrm{I}} / \mathrm{T}_{\mathrm{TOT}}$, inspiratory time ratio; $\mathrm{T}_{\mathrm{T} 0.1}$, tension time index. ${ }^{a}$ Calculated as: $\mathrm{T}_{\mathrm{T} 0.1}$, $\left(\mathrm{P}_{0.1} / \mathrm{P}_{\text {Imax }}\right) \times\left(\mathrm{T}_{\mathrm{I}} / \mathrm{T}_{\mathrm{TOT}}\right) .{ }^{\mathrm{b}}$ In this case, $n=18 .{ }^{\mathrm{c}}$ In this case, $n=22 .{ }^{\mathrm{d}}$ In this case, $n=18 .{ }^{\mathrm{e}}$ In this case, $n=23 .{ }^{\mathrm{f}} \mathrm{In}$ this case, $n=21 .{ }^{\mathrm{g}}$ In this case, $n=26 .{ }^{\mathrm{h}}$ In this case, $n=25 .{ }^{\mathrm{i}}$ In this case, $n=18 .{ }^{\mathrm{j}}$ In this case, $n=22$.

girls (Fig. 2c, d). $\mathrm{T}_{\mathrm{T} 0.1}$ values did not differ between boys and girls and decreased linearly with age (Fig. 3a), even when $\mathrm{T}_{\mathrm{T} 0.1}$ was normalized for FFM (Fig. 3b).

\section{Discussion}

The objective of this study was to provide reference values for respiratory muscle strength and resting work of breathing in healthy children and adolescents aged
8-19 years old. Mean values found in this study for $\mathrm{P}_{\text {Imax }}$ and $\mathrm{P}_{\mathrm{Emax}}$ are comparable with values from previous studies $[10,11,13,14-18]$. Similar to previous studies, our study shows a considerable interindividual variability in respiratory muscle strength values, resulting in wide normal ranges. Also in accordance with other studies, $\mathrm{P}_{\mathrm{I}-}$ $\max$ and $\mathrm{P}_{\mathrm{Emax}}$ values were higher in boys than in girls [10, $13,14,15]$, and the differences between boys and girls increase from the onset of puberty at an age of approximately 12 years. Significant predictors of respiratory 


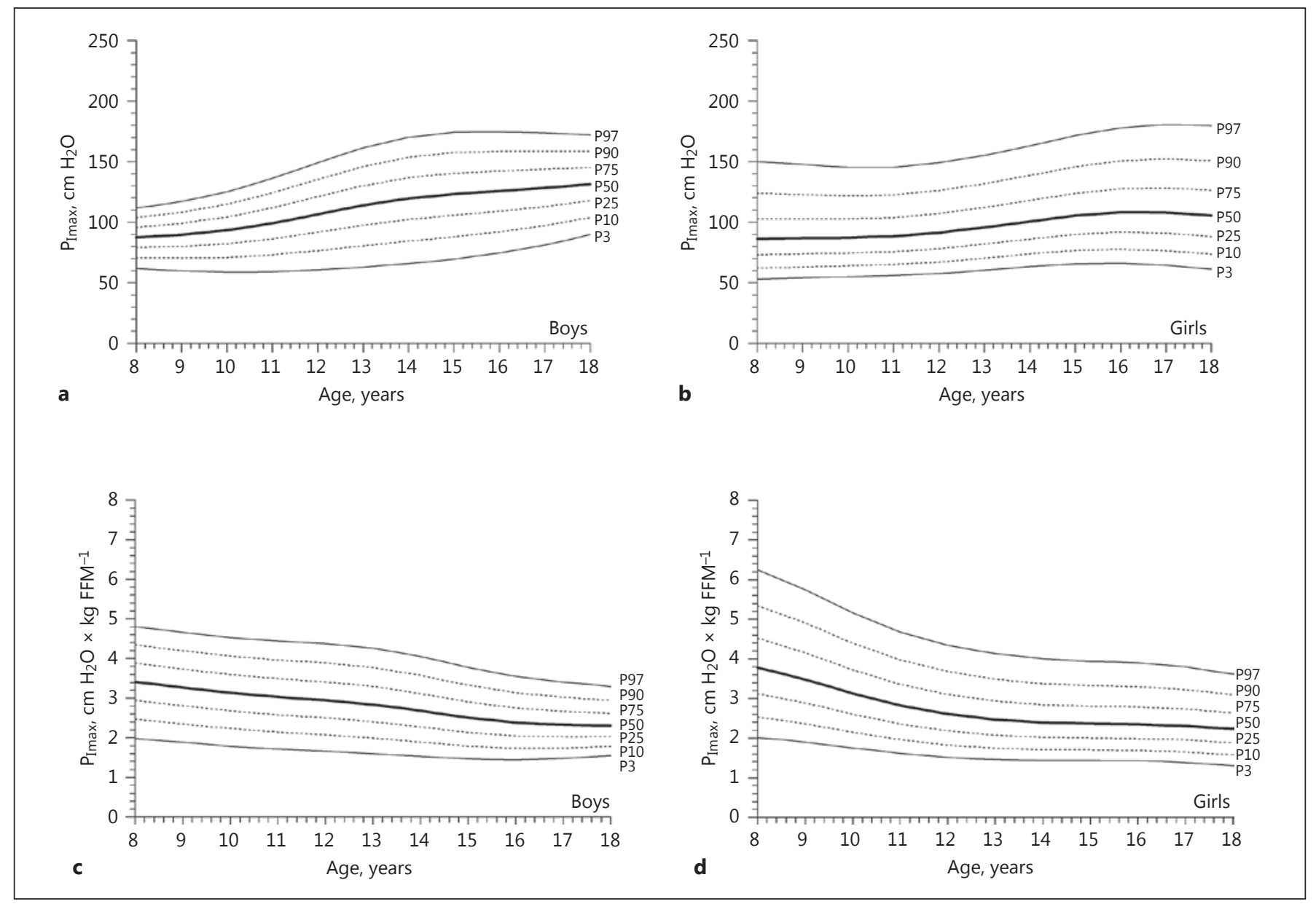

Fig. 1. Age- and sex-related reference values for absolute $P_{\text {Imax }}$ (maximal inspiratory mouth pressure) in boys (a) and girls (b), as well as for $\mathrm{P}_{\text {Imax }}$ normalized for fat-free mass (FFM) in boys (c) and girls (d). The thick solid line represents the 50th percentile (P50);

dotted lines correspond to the 10th, 25th, 75th, and 90th percentiles (P10, P25, P75, and P90, respectively); solid lines indicate the 3rd and 97th percentiles (P3 and P97, respectively).

Table 5. Correlation coefficients for demographic and anthropometric variables with $\mathrm{P}_{\text {Imax }}, \mathrm{P}_{\mathrm{Emax}}$, and $\mathrm{T}_{\mathrm{T} 0.1}$

\begin{tabular}{|c|c|c|c|c|c|c|}
\hline & \multicolumn{3}{|c|}{ Boys $(n=117)$} & \multicolumn{3}{|c|}{ Girls $(n=134)$} \\
\hline & $\mathrm{P}_{\text {Imax }}$ & $\mathrm{P}_{\text {Emax }}$ & $\mathrm{T}_{\mathrm{T} 0.1}^{\mathrm{a}, \mathrm{b}}$ & $\mathrm{P}_{\text {Imax }}$ & $\mathrm{P}_{\text {Emax }}$ & $\mathrm{T}_{\mathrm{T} 0.1}^{\mathrm{a}, \mathrm{c}}$ \\
\hline Age (years) & $0.521^{* * *}$ & $0.498^{* * *}$ & $-0.484^{* * *}$ & $0.271^{* *}$ & $0.324^{* * *}$ & $-0.394^{* * *}$ \\
\hline Body mass (kg) & $0.500^{* * *}$ & $0.476^{* * *}$ & $-0.249^{*}$ & $0.322^{* * *}$ & $0.321^{* * *}$ & $-0.282^{* *}$ \\
\hline Body height (cm) & $0.487^{* * *}$ & $0.422^{* * *}$ & $-0.422^{* * *}$ & $0.271^{* *}$ & $0.294^{* *}$ & $-0.357^{* * *}$ \\
\hline Age from PHV (years) & $0.524^{* * *}$ & $0.516^{* * *}$ & $-0.440^{* * *}$ & $0.294^{* *}$ & $0.331^{* * *}$ & $-0.394^{* * *}$ \\
\hline BMI & $0.374^{* * *}$ & $0.399^{* * *}$ & -0.008 & $0.268^{* *}$ & $0.246^{* *}$ & -0.135 \\
\hline $\mathrm{BSA}\left(\mathrm{m}^{2}\right)$ & $0.512^{* * *}$ & $0.477^{* * *}$ & $-0.301^{* *}$ & $0.319^{* * *}$ & $0.321^{* * *}$ & $-0.303^{* *}$ \\
\hline Body fat (\%) & -0.032 & -0.011 & $0.243^{*}$ & 0.109 & 0.042 & 0.066 \\
\hline FFM (kg) & $0.537^{* * *}$ & $0.508^{* * *}$ & $-0.324^{* *}$ & $0.330^{* * *}$ & $0.341^{* * *}$ & $-0.334^{* * *}$ \\
\hline
\end{tabular}

BMI, body mass index; BSA, body surface area; FFM, fat-free mass; $\mathrm{PHV}$, peak height velocity; $\mathrm{P}_{\mathrm{Emax}}$, maximal expiratory pressure; $\mathrm{P}_{\mathrm{Imax}}$, maximal inspiratory pressure; $\mathrm{T}_{\mathrm{T} 0.1}$, tension time index. ${ }^{*} p<0.05$; ${ }^{* *} p<0.01$; ${ }^{* * *} p<$ 0.001. ${ }^{\mathrm{a}}$ Calculated as: $\mathrm{T}_{\mathrm{T} 0.1},\left(\mathrm{P}_{0.1} / \mathrm{P}_{\mathrm{Imax}}\right) \times\left(\mathrm{T}_{\mathrm{I}} / \mathrm{T}_{\mathrm{TOT}}\right) .{ }^{\mathrm{b}}$ In this case, $n=103 .{ }^{\mathrm{c}}$ In this case, $n=107$. 


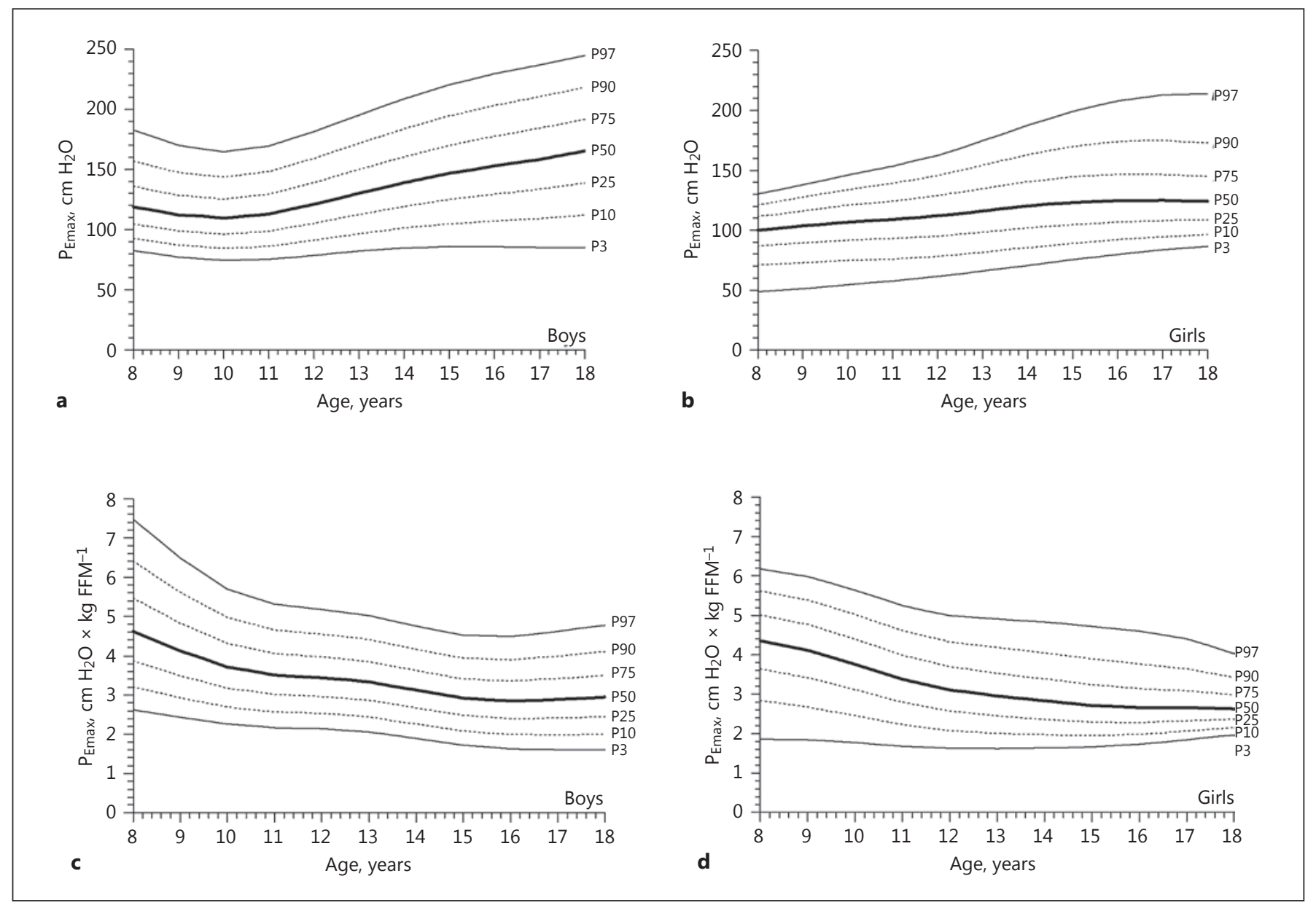

Fig. 2. Age- and sex-related reference values for absolute $P_{\text {Emax }}$ (maximal expiratory mouth pressure) in boys (a) and girls (b), as well as for $\mathrm{P}_{\mathrm{Emax}}$ normalized for fat-free mass (FFM) in boys (c) and girls (d). The thick solid line represents the 50th percentile

muscle strength for boys and girls in this study were age, body mass, body height, age from PHV, BMI, BSA, and FFM.

This is the first study that also investigated the association of FFM with respiratory muscle strength in healthy children and adolescents. For the prediction of $\mathrm{P}_{\operatorname{Imax}}$ and $\mathrm{P}_{\text {Emax }}$ in boys and girls, FFM seems to be of even greater importance than age. This is in accordance with previous research in children with cystic fibrosis $[4,5]$, where lean body mass and upper arm muscle area, as parameters of muscle bulk, were strong predictors of respiratory muscle strength. A previous study of reference values for grip strength in healthy children also showed that FFM is an important predictor of grip strength [27]. In contrast, our results suggest that $\mathrm{BMI}$ and/or the percentage of body fat are not related to respiratory muscle strength in healthy

(P50); dotted lines correspond to the 10th, 25th, 75th, and 90th percentiles (P10, P25, P75, and P90, respectively); solid lines indicate the 3rd and 97th percentiles ( $\mathrm{P} 3$ and $\mathrm{P} 97$, respectively).

children. This is consistent with the study of Arnall et al. [17], where it was also found that BMI was not significantly correlated with respiratory muscle strength. So, in addition to sex and age, FFM seems to predominantly influence respiratory muscle strength in healthy children and adolescents.

The correlation coefficients of anthropometric measurements with respiratory muscle strength are systematically higher in boys than in girls, resulting in a larger explained variance for boys. Other studies show similar differences between boys and girls $[14,15,17]$. An explanation for the differences in explained variance between boys and girls may be found in the fact that $\mathrm{P}_{\text {Imax }}$ and $\mathrm{P}_{\text {Emax }}$ values show larger and more pronounced increase with age in boys compared with girls. Therefore, it is not surprising that the variance in respiratory muscle strength 


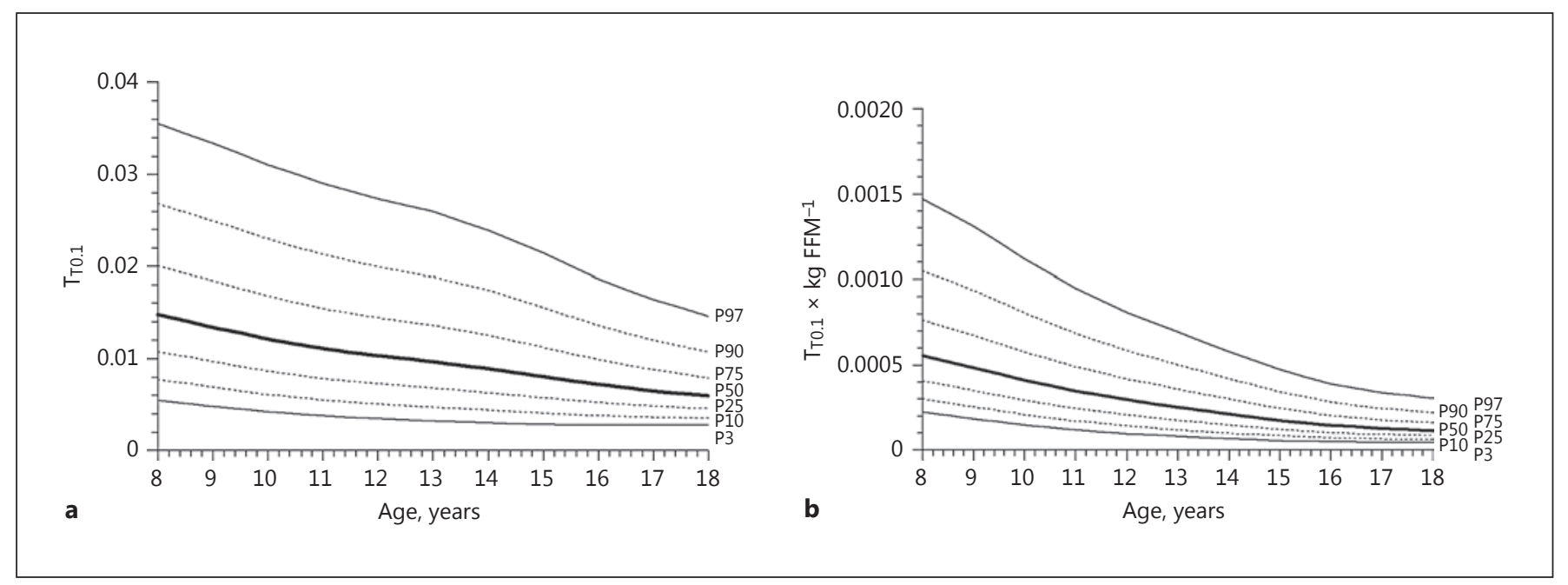

Fig. 3. Age-related reference values for absolute $\mathrm{T}_{\mathrm{T} 0.1}$ (noninvasive tension time index) at rest (a) as well as for $\mathrm{T}_{\mathrm{T} 0.1}$ at rest normalized for fat-free mass (FFM) (b). The thick solid line represents the 50th percentile (P50); dotted lines correspond to the 10th, 25th, 75th,

in girls cannot sufficiently be explained by age or by other variables such as FFM, since these variables are strongly correlated with age.

$\mathrm{T}_{\mathrm{T} 0.1}$ is a suitable noninvasive measurement of work of breathing [18, 28-30]. For example, studies demonstrate that $\mathrm{T}_{\mathrm{T} 0.1}$ increases with disease progression in boys with Duchenne muscular dystrophy [31] and decreases after use of noninvasive ventilation as a measure of inspiratory muscle unloading [32]. Follow-up of respiratory muscle tests in children and adolescents should include noninvasive $\mathrm{T}_{\mathrm{T} 0.1}$ determinations for assessment of disease progression. Particularly in children and adolescents with neuromuscular disorders who are prone to respiratory muscle fatigue, $\mathrm{T}_{\mathrm{T} 0.1}$ may be useful in assessing tolerance during weaning from mechanical ventilation, identifying impending respiratory failure, and aiding in the decision for therapies (e.g., mechanical ventilation or respiratory muscle training) [8]. As such, reference values of $\mathrm{T}_{\mathrm{T} 0.1}$ are clinically meaningful; however, more research is necessary to determine thresholds for respiratory muscle failure, especially in children with neuromuscular disorders [33].

Further research in reliable noninvasive and cooperation-independent measurements of the respiratory system might improve our knowledge of respiratory muscle function in children and adolescents in health and disease. Especially in patients with decreased oral control such as cerebral palsy and neuromuscular disorders and and 90th percentiles (P10, P25, P75, and P90, respectively); solid lines indicate the 3rd and 97th percentiles (P3 and P97, respectively). in very weak patients, nonvolitional techniques might be more valuable. In children and adults with various neuromuscular and skeletal disorders, inspiratory muscle strength can be easily assessed with the sniff nasal pressure [34].

In conclusion, this study provides reference values for $\mathrm{P}_{\text {Imax }}, \mathrm{P}_{\mathrm{Emax}}$, and $\mathrm{T}_{\mathrm{T} 0.1}$ for children aged 8-19 years. The findings of this study can be used in clinical practice to interpret individual test results. In addition to sex and age, FFM was found to be an important predictor of respiratory muscle strength.

\section{Acknowledgements}

The authors thank the participating schools (Basisschool Lucas Galecop, Nieuwegein, the Netherlands; Cals College, Nieuwegein, the Netherlands; Graaf Huyn College, Geleen, the Netherlands; Wellantcollege, Gorinchem, the Netherlands) and Zuyd University of Applied Sciences (School of Biometrics and School of Physiotherapy), Heerlen, the Netherlands. The authors are especially grateful to all participants.

\section{Funding Sources}

This study was funded by an unconditional research grant from Scientific Committee Physiotherapy of the Royal Dutch Society for Physiotherapy. 


\section{References}

1 American Thoracic Society/European Respiratory Society: ATS/ERS Statement on respiratory muscle testing. Am J Respir Crit Care Med 2002;166:518-624.

2 Ronchi CF, Antunes LC, Fioretto JR: Respiratory muscular strength decrease in children with myelomeningocele. Spine (Phila Pa 1976) 2008;33:E73-E75.

3 Dassios T, Katelari A, Doudounakis S, Dimitriou G: Aerobic exercise and respiratory muscle strength in patients with cystic fibrosis. Respir Med 2013;107:684-690.

4 Dassios T, Katelari A, Doudounakis S, Mantagos S, Dimitriou G: Respiratory muscle function in patients with cystic fibrosis. Pediatr Pulmonol 2013;48:865-873.

5 Hayot M, Guillaumont S, Ramonatxo M, Voisin M, Prefaut C: Determinants of the tension-time index of inspiratory muscles in children with cystic fibrosis. Pediatr Pulmonol 1997;23:336-343.

6 Hayot M, Ramonatxo M, Matecki S, MilicEmili J, Prefaut C: Noninvasive assessment of inspiratory muscle function during exercise. Am J Respir Crit Care Med 2000;162:22012207.

7 Hahn A, Ankermann T, Claass A, Mann M, Lindemann H, Neubauer BA: Non-invasive tension time index in relation to severity of disease in children with cystic fibrosis. Pediatr Pulmonol 2008;43:973-981.

8 Mulreany LT, Weiner DJ, McDonough JM, Panitch HB, Allen JL: Noninvasive measurement of the tension-time index in children with neuromuscular disease. J Appl Physiol (1985) 2003;95:931-937.

9 Harikumar G, Egberongbe Y, Nadel S, Wheatley E, Moxham J, Greenough A, Rafferty GF: Tension-time index as a predictor of extubation outcome in ventilated children. Am J Respir Crit Care Med 2009;180:982-988.

10 Gaultier C, Zinman R: Maximal static pressures in healthy children. Respir Physiol 1983; 51:45-61.

11 Smyth RJ, Chapman KR, Rebuck AS: Maximal inspiratory and expiratory pressures in adolescents. Normal values. Chest 1984;86: 568-572.

12 Wagener JS, Hibbert ME, Landau LI: Maximal respiratory pressures in children. Am Rev Respir Dis 1984;129:873-875.
13 Wilson SH, Cooke NT, Edwards RH, Spiro SG: Predicted normal values for maximal respiratory pressures in Caucasian adults and children. Thorax 1984;39:535-538.

14 Tomalak W, Pogorzelski A, Prusak J: Normal values for maximal static inspiratory and expiratory pressures in healthy children. Pediatr Pulmonol 2002;34:42-46.

15 Domenech-Clar R, Lopez-Andreu JA, Compte-Torrero L, De Diego-Damia A, Macian-Gisbert V, Perpina-Tordera M, RoquesSerradilla JM: Maximal static respiratory pressures in children and adolescents. Pediatr Pulmonol 2003;35:126-132.

16 Cox DW, Verheggen MM, Stick SM, Hall GL: Characterization of maximal respiratory pressures in healthy children. Respiration 2012;84:485-491.

17 Arnall DA, Nelson AG, Owens B, Cebria i Iranzo MA, Sokell GA, Kanuho V, Interpreter C, Coast JR: Maximal respiratory pressure reference values for Navajo children ages 6-14. Pediatr Pulmonol 2013;48:804-808.

18 Mellies U, Stehling F, Dohna-Schwake C: Normal values for inspiratory muscle function in children. Physiol Meas 2014;35:19751981.

19 Haycock GB, Schwartz GJ, Wisotsky DH: Geometric method for measuring body surface area: a height-weight formula validated in infants, children, and adults. J Pediatr 1978; 93:62-66.

20 Deurenberg P, van der Kooy K, Hautvast JG: The assessment of the body composition in the elderly by densitometry, anthropometry and bioelectrical impedance. Basic Life Sci 1990;55:391-393.

21 Weststrate JA, Deurenberg P: Body composition in children: proposal for a method for calculating body fat percentage from total body density or skinfold-thickness measurements. Am J Clin Nutr 1989;50:1104-1115.

22 Miller MR, Hankinson J, Brusasco V, Burgos F, Casaburi R, Coates A, Crapo R, Enright P, van der Grinten CP, Gustafsson P, Jensen R, Johnson DC, MacIntyre N, McKay R, Navajas D, Pedersen OF, Pellegrino R, Viegi G, Wanger J; ATS/ERS Task Force: Standardisation of spirometry. Eur Respir J 2005;26:319338.
23 Koopman M, Zanen P, Kruitwagen CL, van der Ent CK, Arets HG: Reference values for paediatric pulmonary function testing: The Utrecht dataset. Respir Med 2011;105:15-23.

24 Cole TJ: Fitting smoothed centile curves to reference data. J R Stat Soc 1988;151:385-418.

25 Cole TJ: The LMS method for constructing normalized growth standards. Eur J Clin Nutr 1990;44:45-60.

26 Fredriks AM, van Buuren S, Wit JM, Verloove-Vanhorick SP: Body index measurements in 1996-7 compared with 1980. Arch Dis Child 2000;82:107-112.

27 de Souza MA, de Jesus Alves de Baptista CR, Baranauskas Benedicto MM, Pizzato TM, Mattiello-Sverzut AC: Normative data for hand grip strength in healthy children measured with a bulb dynamometer: a cross-sectional study. Physiotherapy 2014;100:313318.

28 Decramer M, Scano G: Assessment of respiratory muscle function. Eur Respir J 1994;7: 1744-1745.

29 Mellies U, Dohna-Schwake C, Voit T: Respiratory function assessment and intervention in neuromuscular disorders. Curr Opin Neurol 2005; 18:543-547.

30 Fauroux B, Aubertin G, Clément A, Lofaso F, Bonora $\mathrm{M}$ : Which tests may predict the need for noninvasive ventilation in children with neuromuscular disease? Respir Med 2009; 103:574-581.

31 Hahn A, Duisberg B, Neubauer BA, Stephani U, Rideau Y: Noninvasive determination of the tension-time index in Duchenne muscular dystrophy. Am J Phys Med Rehabil 2009; 88:322-327.

32 Koessler W, Wanke T, Winkler G, Nader A, Toifl K, Kurz H, Zwick H: 2 years' experience with inspiratory muscle training in patients with neuromuscular disorders. Chest 2001; 120:765-769.

33 Stehling F, Alfen K, Dohna-Schwake C, Mellies U: Respiratory muscle weakness and respiratory failure in pediatric neuromuscular disorders: the value of noninvasive determined tension-time index. Neuropediatrics 2016;47:374-379.

34 Stefanutti D, Benoist MR, Scheinmann P Chaussain M, Fitting JW: Usefulness of sniff nasal pressure in patients with neuromuscular or skeletal disorders. Am J Respir Crit Care Med 2000;162:1507-1511. 